\title{
Alleviation of oxidative stresses by potassium fertilizer in spring maize under early and late sown conditions
}

\author{
I. Ahmad ${ }^{\text {1* }}$, S.M.A. Basra ${ }^{2}$, M. Akram ${ }^{3}$, Allah Wasaya ${ }^{4}$, S.A. Hussain ${ }^{5}$ and Asif Iqbal ${ }^{6}$ \\ ${ }^{1}$ Soil Conservation Officer, Pindi Road Talagang, District Chakwal, Pakistan \\ ${ }^{2}$ Department of Crop Physiology, University of Agriculture, Faisalabad, Pakistan \\ ${ }^{3}$ Department of Environmental Sciences, COMSATS Institute of Information Technology, Vehari, Pakistan \\ ${ }^{4}$ Department of Agronomy, Bahaudar Campus Layyiah of Bahauddin Zakrayia University, Multan, Pakistan \\ ${ }^{5}$ Assistant Research Officer, Divisional Soil and Water Testing Laboratory, Sargodha, Pakistan \\ ${ }^{6}$ On Farm Water Management Department, Mandi Bahauddin, Pakistan
}

\begin{abstract}
The yield potential of spring planted maize is much higher than autumn crop. Heat stress at during anthesis and grain formation stage is one of the main hindrances in its spring cultivation especially under late sown conditions but early sowing seems an ideal solution to escape from heat spell which may cause poor stand establishment. Both temperature extremes cause oxidative stresses and potassium application may lessen the damage. The present paper aims to contribute the role of potassium application in alleviation of oxidative damage and improvement in stress tolerance of early and late sown spring maize. The experiment was carried out in randomized complete block design (RCBD) with split plot arrangement randomizing the sowing dates Early, Mid and Late in main plots and potassium levels $\mathrm{K}_{0}(0)$, $\mathrm{K}_{1}(100)$ and $\mathrm{K}_{2}\left(200 \mathrm{~kg} \mathrm{ha}^{-1}\right)$ in sub-plots. Data on growth parameters were recorded fortnightly starting from 30 to 90 days after sowing by using standard procedure while relative water and chlorophyll contents, peroxidase (POD) and catalase (CAT) activities were measured at both tasselling and blister stage. Growth was reduced under both early and late sown conditions but potassium application improved it by enhancing antioxidants defense system which protects leaf chlorophyll contents under early and late sown conditions. Furthermore, antioxidants like CAT and POD activities were increased while $\mathrm{SOD} /[\mathrm{POD}+\mathrm{CAT}]$ were decreased with increase in potassium and age. It is suggested that $100 \mathrm{~kg} \mathrm{ha}^{-1}$ potassium reduced oxidative damage and improved stress tolerance of spring maize.
\end{abstract}

Keywords: Potassium; Chilling; Heat stress; Antioxidants; Chlorophyll

\section{Introduction}

The yield potential of spring maize is much higher than autumn sown maize but higher temperature at reproductive stage is a severe constraint to achieve its yield potential. Maize, being monoacious is extremely sensitive to higher temperature and drought stress during flowering and grain formation (Johnson and Herrero, 1981). The heat stress produces reactive oxygen species (ROS) which causes oxidative damage to various macromolecules as well as cellular structures (Noctor and Foyor, 1998; Apel and Hirt, 2004). Important functional units especially photosynthetic apparatus also become susceptible to negative effects of low temperature (Janda et al., 1994).

Early sowing of spring maize crop can be an adaptive strategy to avoid the lethal heat period during anthesis and seed maturity. Temperature extremes are still a serious problem and are important factors contributing to crop yield losses. For maize grown in Pakistan, early sowing may improve yield but faced with low temperature during initial growth stage and heat stress at reproductive stage are main challenges to maize production. Inevitably both these temperature extremes leads to oxidative stress in plant cell due to higher leakage of electrons towards $\mathrm{O}_{2}$ during photosynthesis and respiration processes leading to higher production of ROS (Asada, 1999). ROS like $\mathrm{O}_{2}^{-}, \mathrm{H}_{2} \mathrm{O}_{2}$ and $\mathrm{OH}$ - radicals can directly attack membrane lipids, inactivate metabolic enzymes and nucleic acid leading to cell death (Ouchi et al., 1990). Being toxic to cells, ROS are eliminated by enzymatic and non-enzymatic antioxidants (Noctor and Foyer, 1998).

\footnotetext{
*Corresponding author. e-mail: ijazscogujrat@gmail.com
} 
Potassium (K) plays an important role in balancing membrane potential and turgor, activation (Tisdale et al., 1990) and stabilization of enzymes (Balasubramian and Palaniappan, 2001), regulation of osmotic pressure and stomatal movement (Cherel, 2004). Soleimanzadeh et al. (2010) reported that higher levels of (K) induced drought tolerance in sunflower through enhancing antioxidant activities and reducing membrane damage. It regulates photosynthesis, nutrient uptake, assimilate transport and enzyme activation for protein synthesis (Meille and Pellerin, 2004). This study is based on the rationale that pentose phosphate pathway may play a crucial role under low temperature stress in maize and as a result, $\mathrm{K}$ can effectively counter oxidative stress within the cell during both low and high temperature stress through stimulation of the antioxidant enzyme response. Therefore, the present study was aimed at exploring the role of $\mathrm{K}$ application in alleviation of oxidative damage and improvement in stress tolerance and growth of early and late sown spring maize.

\section{Materials and methods}

\section{Sowing and experimental design}

The experiment was carried out in randomized complete block design (RCBD) with split plot arrangement randomizing the sowing dates i.e.1st February (Early), 22nd February (Mid) and 15th March (Late) in main plots and different K levels $\left(0,100\right.$ and $\left.200 \mathrm{~kg} \mathrm{ha}^{-1}\right)$ in sub-plots using three replications at latitude of $31.26 \mathrm{oN}$, longitude of $73.06 \mathrm{oE}$ and altitude of $184.4 \mathrm{~m}$ using maize hybrid-Hi Sawn 9697. Meteorological data on the mean maximum/minimum temperatures, relative humidity (R.H) and sun shine hour were recorded at the Department of Crop Physiology, while field experiments were carried out at research area, Department of Plant Breeding and Genetics, University of Agriculture, Faisalabad, during 2008 (Table I). The soil samples were randomly collected from the field at two different depths of 0-15 and 16-30 cm and were analyzed for different soil physico-chemical properties. The data on different soil physico-chemical properties is presented in Table II. The net plot size was kept $3.6 \mathrm{~m} \times 8.0 \mathrm{~m}$. The crop was sown at 60
Table I. Meteorological data of the experimental site from 1st February 2008 to 31st July, 2008 at Latitude of $31.260 \mathrm{~N}$, Longitude of $73.060 \mathrm{E}$ and Altitude of $184.4 \mathrm{~m}$

\begin{tabular}{lccccc}
\hline $\begin{array}{l}\text { Weeks } \\
\text { after } \\
\text { sowing }\end{array}$ & $\begin{array}{r}\text { Maximum } \\
\text { Temp. } \\
\left({ }^{\circ} \mathrm{C}\right)\end{array}$ & $\begin{array}{r}\text { Minimum } \\
\text { Temp. } \\
\left({ }^{\circ} \mathrm{C}\right)\end{array}$ & $\begin{array}{r}\text { Average } \\
\text { Temp. } \\
\left({ }^{\circ} \mathrm{C}\right)\end{array}$ & $\begin{array}{c}\text { Relative } \\
\text { humidity } \\
(\%)\end{array}$ & $\begin{array}{c}\text { Rainfall } \\
(\mathrm{mm})\end{array}$ \\
\hline 1 & 31.1 & 16.2 & 23.6 & 39.6 & 0.8 \\
2 & 28.6 & 17.1 & 22.9 & 47.3 & 0.3 \\
3 & 31.4 & 17.9 & 24.6 & 37.1 & 1.2 \\
4 & 37.4 & 21.2 & 29.3 & 22.9 & 0.0 \\
5 & 40.8 & 21.8 & 31.3 & 15.7 & 0.0 \\
6 & 40.8 & 24.4 & 32.6 & 19.9 & 0.3 \\
7 & 37.8 & 23.1 & 30.5 & 30.4 & 1.6 \\
8 & 38.8 & 25.1 & 32.0 & 35.0 & 1.6 \\
9 & 34.9 & 22.5 & 28.7 & 40.1 & 7.3 \\
10 & 39.9 & 28.3 & 34.1 & 31.9 & 0.0 \\
11 & 38.9 & 27.9 & 33.4 & 46.3 & 1.9 \\
12 & 38.0 & 26.1 & 32.0 & 51.3 & 2.3 \\
13 & 37.7 & 28.0 & 32.9 & 53.3 & 0.6 \\
14 & 37.9 & 27.9 & 32.9 & 53.3 & 1.2 \\
15 & 36.9 & 28.0 & 32.4 & 55.3 & 2.6 \\
16 & 36.3 & 26.7 & 31.5 & 61.0 & 2.0 \\
17 & 37.4 & 28.1 & 32.7 & 52.3 & 7.0 \\
18 & 33.4 & 25.4 & 29.4 & 39.7 & 0.0 \\
19 & 0.0 & 0.0 & 0.0 & 0.0 & 0.0 \\
\hline
\end{tabular}

$\mathrm{cm}$ apart rows at respective sowing dates and two seeds were dibbled at $15 \mathrm{~cm}$ apart hole and then one plant per hill was maintained by thinning at three-leaf stage. The NP@200, $100 \mathrm{~kg} \mathrm{ha}^{-1}$ as Urea and DAP and K as Sulphate of Potash (SOP) as per treatment were mixed and side drilled along with seeding rows respectively. Half of the total dose of

Table II. Physiochemical properties of soil used in the experiment

\begin{tabular}{lccc}
\hline $\begin{array}{l}\text { Physiochemical } \\
\text { properties of soil }\end{array}$ & Units & \multicolumn{2}{c}{ Value } \\
\hline Textural classes & & 0-15 cm depth & $16-30 \mathrm{~cm}$ depth \\
Organic matter & $\%$ & 0.964 & Loam \\
PH & - & 7.411 & 0.358 \\
ECe & $\left(\mathrm{dSm}^{-1}\right)$ & 0.427 & 0.40 \\
Available K & $(\mathrm{ppm})$ & 374.44 & 326.67 \\
Available P & $(\mathrm{ppm})$ & 13.93 & 11.718 \\
Saturation & & & \\
percentage & $(\%)$ & 36.11 & 34.55 \\
\hline
\end{tabular}


nitrogen and full dose of phosphorus and potassium were applied at the time of sowing as basal dose while remaining half nitrogen was top dressed with first irrigation. All other agronomic practices were kept normal and uniform for all treatments.

Total dry matter (TDM), leaf area index (LAI) and relative water content (RWC) were measured at 15 days interval starting from 30 days after sowing and ending up to 90 days after sowing by using standard procedure. Data on dry matter accumulation per plant and RWC and superoxide dismutase (SOD) activity of ear leaves were analyzed at 60 and 75 days after sowing (DAS). The procedures adapted for measuring different physiological and biochemical parameters are briefly described below.

\section{Chlorophyll content}

The fresh leaves were cut into $0.5 \mathrm{~cm}$ segments and extracted overnight with $80 \%$ acetone at $-10^{\circ} \mathrm{C}$. After incubation, the extract was centrifuged at $14000-\mathrm{x} g$ for minutes and chlorophyll were determined by using a spectrophotometer $\left(\mathrm{T}_{60}\right.$ spectrophotometer). The absorbance of solutions was measured at 645 and $663 \mathrm{~nm}$ and chlorophyll $a$ and $b$ contents were calculated by Nagata and Yamashita (1992) formulae and total chlorophyll by summation of $a$ and $b$.

\section{Antioxidant enzyme assay}

To extract antioxidant enzymes, $0.5 \mathrm{~g}$ fresh leaves randomly sampled from plants in each pot were ground using a tissue grinder in $8 \mathrm{~mL}$ of cooled phosphate buffer $(\mathrm{pH} 7.0$, containing $1 \%(\mathrm{w} / \mathrm{v})$ polyvinyl pyrrolidone) and $0.2 \mathrm{~g}$ quartz sand in test tubes that were placed in an ice bath. The homogenate was centrifuged at $15000-\mathrm{x}$ g for 20 minutes at $4^{\circ} \mathrm{C}$. The purified extracts were assayed for enzyme activity. Catalase (CAT) and peroxidase (POD) activities were measured using the method of Chance and Maehly (1955) with modification where $\mathrm{H}_{2} \mathrm{O}_{2}$ was followed spectrophotometrically at $240 \mathrm{~nm}$ and read every $20 \mathrm{~s}$. One unit CAT activity was defined as an absorbance change of 0.01 units per minute. The POD reaction solution $(3 \mathrm{~mL})$ contained $50 \mathrm{mM}$ sodium acetate buffer

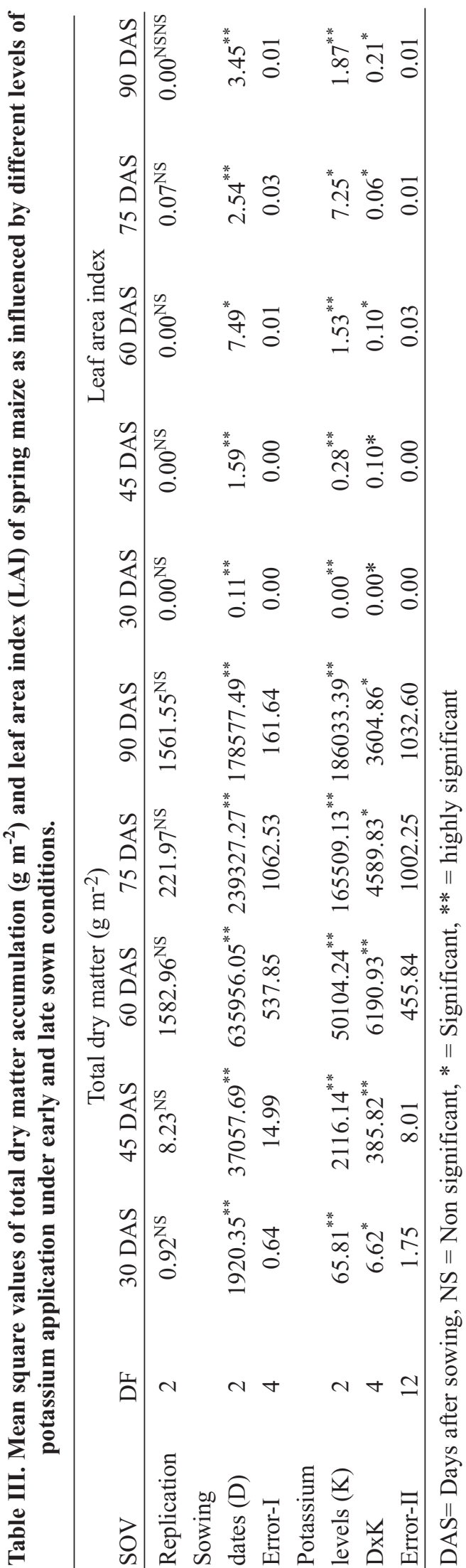


(pH 5.0), $20 \mathrm{mM}$ guaiacol, $40 \mathrm{mM} \mathrm{H}_{2} \mathrm{O}_{2}$ and $0.1 \mathrm{~mL}$ enzyme extract. Changes in absorbance of reaction solution at 470 $\mathrm{nm}$ were determined every $20 \mathrm{~s}$. One unit POD activity was defined as an absorbance change of 0.01 units per minute. The activity of each enzyme was expressed on a protein basis.

\section{Statistical analysis}

The data collected were analyzed statistically using Fisher's analysis of variances technique and treatment means showing F-values significant were compared by using least significant difference test at 0.05 probability level (Steel et al., 1997).

\section{Results and discussion}

Plant growth

TDM and LAI of spring maize were increased with age of plant while LAI declined afterwards at 75 DAS (Fig. 1 and $2)$. The poor and steady early seedling growth in terms of TDM and LAI were observed at 30 and 45 DAS when crop was planted on 1st February and subjected to low temperature. 15th March planted crop have comparatively higher growth and faster at 30 DAS and 45 DAS than optimum planting (Fig. 1 and 2). Lower TDM and LAI were produced under stressful environmental condition but $\mathrm{K}$ application improved them even under stressful conditions of early and late planting (Table III and IV). Since plant absorbs the bulk of $\mathrm{K}^{+}$from soil to maintain growth and development (Maathuis and Sanders 2006), increased TDM in maize with $\mathrm{K}$ application under low and high temperature stress during early and late sown

conditions might be due to induced carboxylation efficiency. Higher K level has been known to enhance photosynthesis which was depicted with increased chlorophyll contents and enhanced antioxidant activity. These results were also supported by Kafkafi (1990) who also reported increased K application alleviate adverse effects imposed by both extremes of temperature.

Chilling / low temperature in maize is known to reduce the leaf size which lowers the cell division and elongation (Salah and Tardieu, 1995). LAI reduced in early planting maize may be attributed to chilling but adequate $\mathrm{K}$ increased LAI by mitigating adverse effects of low temperature on leaf turgor and cell wall extensibility (Table III and IV). Pettigrew (2008) and Meille and Pellerin (2008) also reported that K

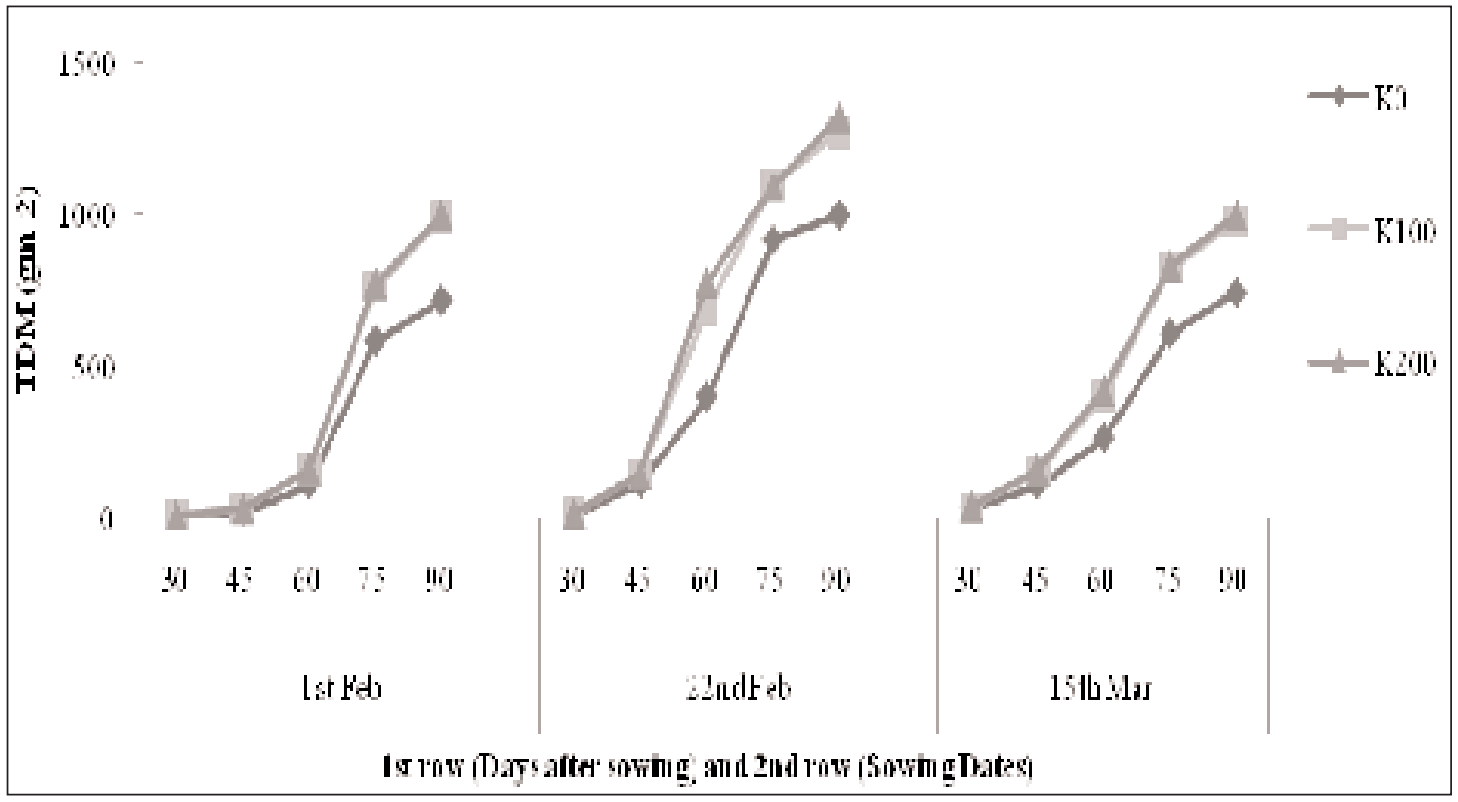

Fig. 1. TDM of spring maize as influenced by potassium application under and late sown condions 


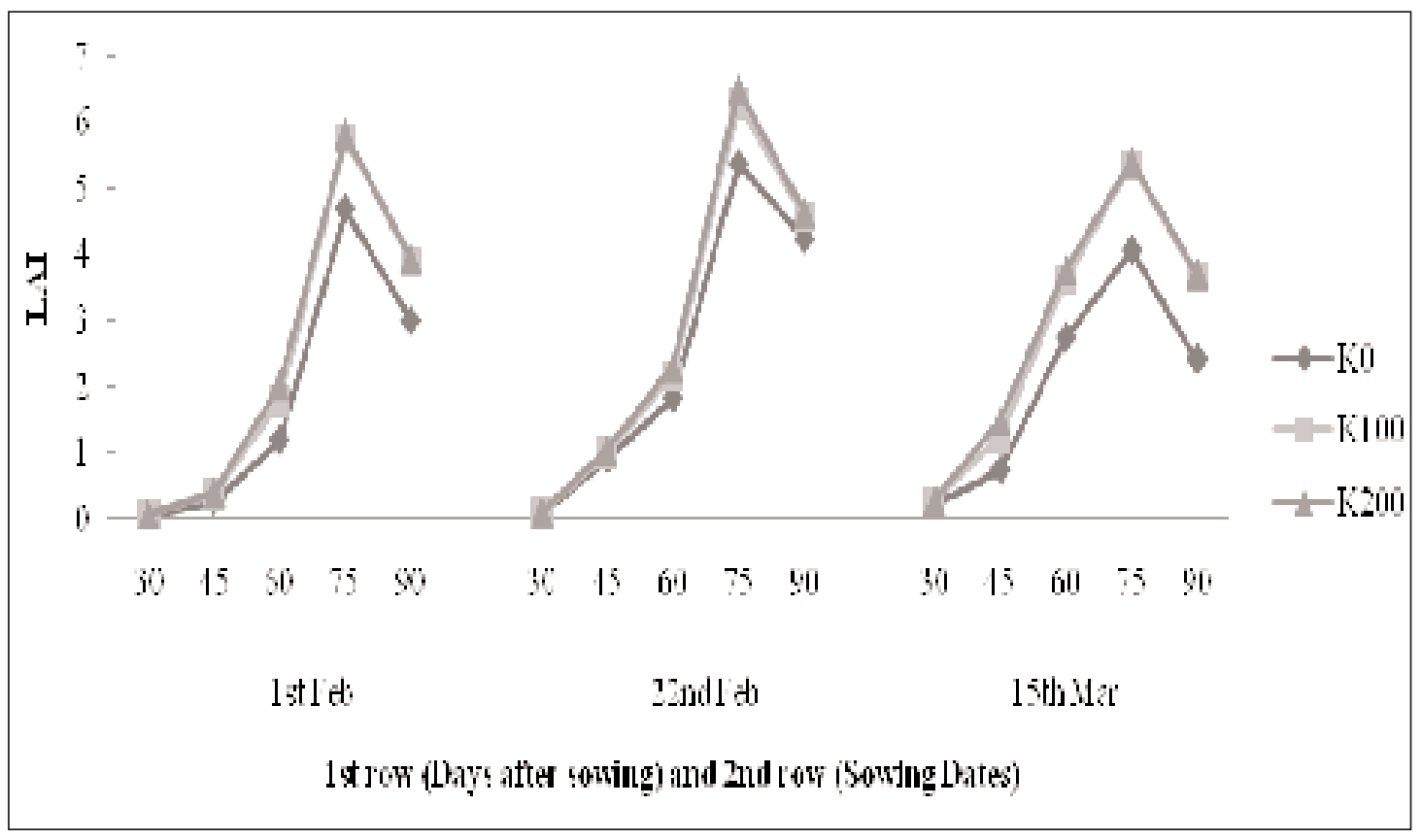

Fig. 2. LAI of spring maize as influenced by potassium under and late sown condions

application improve LAI as a result of involvement of $\mathrm{K}$ in cell growth by increased turgor pressure and cell wall extensibility in maize. The beneficial effect of K may be due to its role as osmoprotectant that protected maize plant from oxidative damage induced by low temperature stresses.

\section{Antioxidant activities}

Both CAT and POD activities were reduced during stressful conditions of early (1st February) and late (15th February) planting while $\mathrm{K}$ application increased these antioxidant enzyme activities (Table V and VI). The reduction of CAT and POD activities might be due to differential environmental conditions. The higher activities of both enzymes were observed when crop later planted as well as in later stage than early planting. $\mathrm{K}$ application induced CAT and POD activities when planted in different sowing dates at both stages (Table V). As CAT and POD are involved in detoxifying and scavenging the product of oxidative stress like $\mathrm{H}_{2} \mathrm{O}_{2}$, the increased CAT and POD activities with potassium application help in reducing the adverse effects of oxidative damage. It is in good agreement emphasizing the role of potassium in alleviating adverse effects of a number of abiotic factors on crop production (Ismail, 2005; Sairam et al., 1997; Cakmak, 2005).

\section{$S O D /[C A T+P O D]$ leaf activity ratio}

Although SOD is not the only $\mathrm{H}_{2} \mathrm{O}_{2}$-producing enzyme in plants, the balance between the activity of this enzyme and that of the $\mathrm{H}_{2} \mathrm{O}_{2}$-scavenging enzymes in cells has been considered to be crucial in determining the levels of $\mathrm{O}_{2}$ and $\mathrm{H}_{2} \mathrm{O}_{2}$ (Badawi et al., 2004). It was observed that $\mathrm{SOD} /[\mathrm{CAT}+\mathrm{POD}]$ leaf activity ratio was increased at tasselling and blister stage when subjected to low and high tem perature, respectively (Table V and VI). Potassium application reduced this activity ratio at both stages of maize crop. It is therefore suggested that the balance between the activity of $\mathrm{H}_{2} \mathrm{O}_{2}$-producing enzymes and that of the $\mathrm{H}_{2} \mathrm{O}_{2}$-scavenging enzymes plays important role in providing a plant defense mechanism against stress induced oxidative damage. Therefore, the induction of this anti-oxidative defense mechanism could reflect a plant threats imposed by both temperature extremes. 

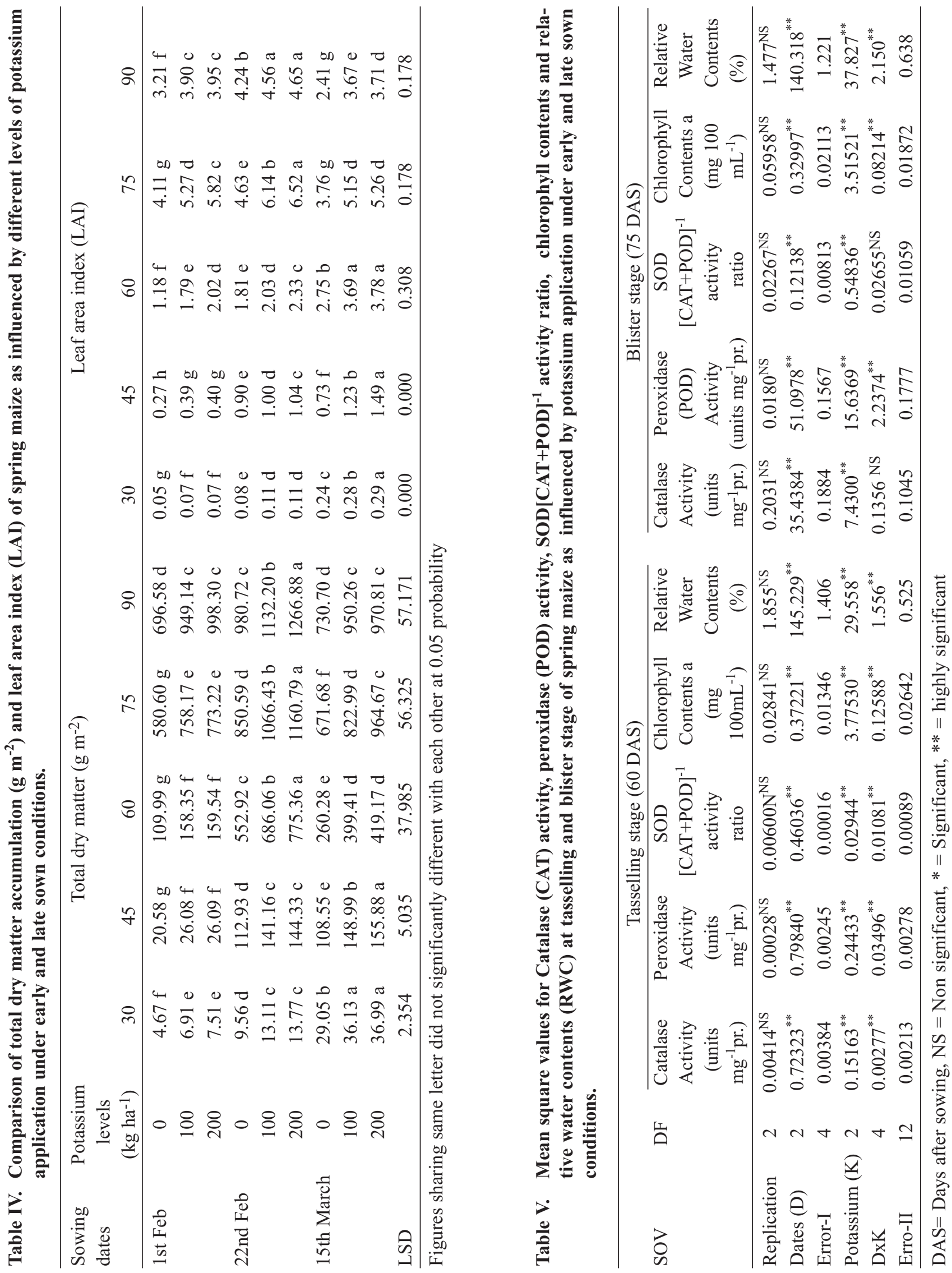


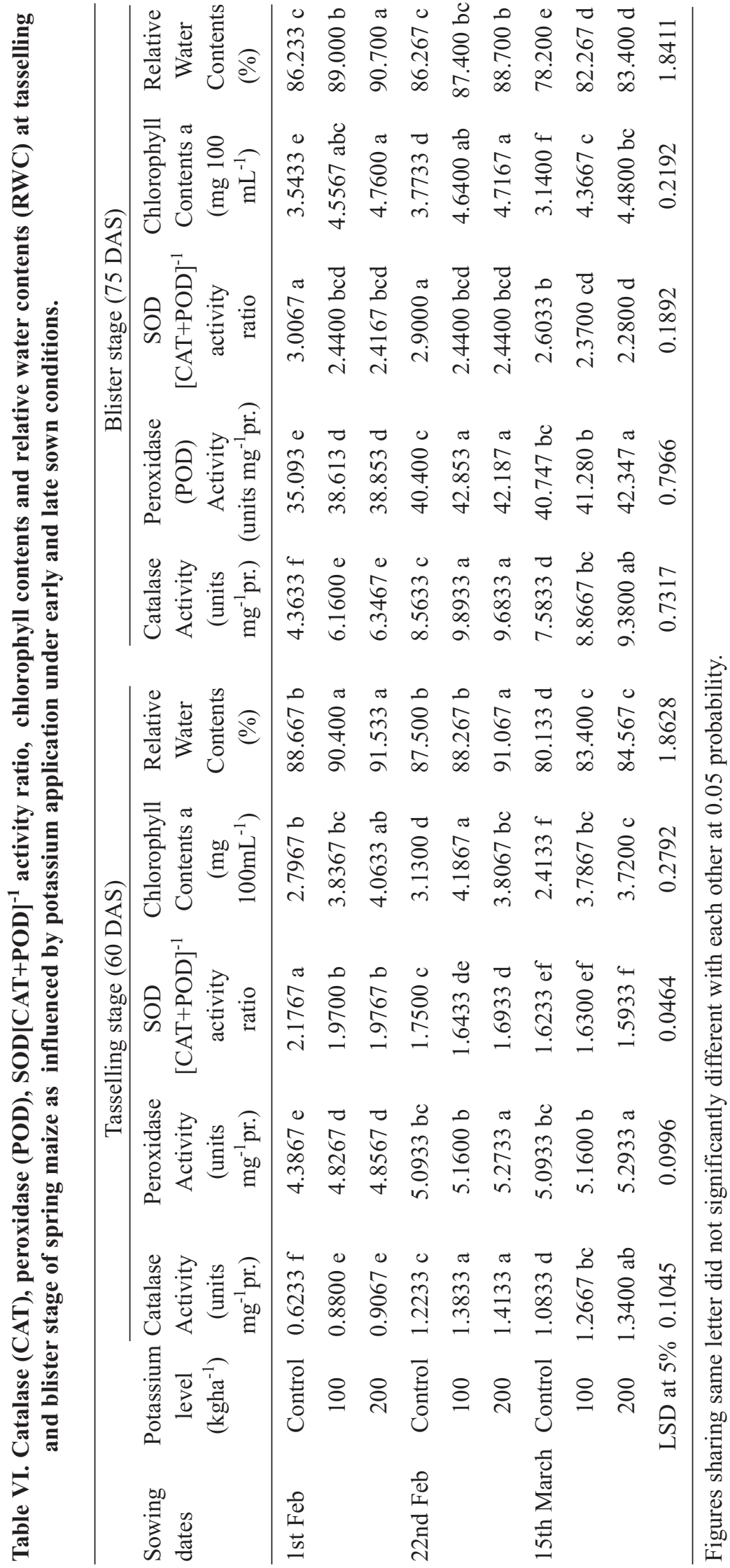




\section{Chlorophyll contents}

Early and late planting reduced ear leaf chlorophyll contents but $\mathrm{K}$ application promoted them at both tasselling and blister stage. These chlorophyll contents were declined with age in both early and late planted maize. However, $\mathrm{K}$ application significantly increased chlorophyll contents in ear leaf at both tasselling stage and blister stage at each sowing dates (Table V and VI). Different levels of K application increased ear leaf chlorophyll at both stages of crop development 60 (Tasselling) and 75 days after sowing (Blister stage) at optimum, early and late sowing dates (Table V). Furthermore, chlorophyll contents in leaves were declined at later stage. At tasselling and blister stages, chlorophyll contents in maize leaf grown at three different sowing dates were in the order of optimum (22nd February) $>$ early (1st February) $>$ late (15th March) sown maize, with different being significant at $\mathrm{p}<0.01$. However, at tasselling and blister stage, chlorophyll contents were significantly less $(p>0.05)$ in optimum than both early and late planting (Table VI). The visible symptoms of injury observed in this investigation as chlorosis may be related to the chlorophyll loss (Table VI). Most researchers connected the reduction of chlorophyll in stressed plants to its biosynthesis (Ahmad et al., 2013, 2014 and 2015) while potassium application increased chlorophyll contents in ear leaf during tasseling and silking stage under both normal and stressful conditions of early and late planting (Table VI). In this connection, Wahid et al. (2007) also reported that a typical sign of chilling and heat stress is visible loss of chlorophylls in leaves of maize and that growing of maize under both temperature extremes showed deleterious effect in photosynthetic processes like reduction of photosynthetic pigments. The visible symptoms of injury observed in this investigation as chlorosis may be related to the chlorophyll loss (Table VI). Most researchers connected the reduction of chlorophyll in stressed plants to its biosynthesis (Ahmad et al., 2013, 2014 and 2015) while potassium application increased chlorophyll contents in ear leaf during tasseling and silking stage under both normal and stressful conditions of early and late planting (Table VI). In this connection, Wahid et al. (2007) also reported that a typical sign of chilling and heat stress is visible loss of chlorophylls in leaves of maize and that growing of maize under both temperature extremes showed deleterious effect in photosynthetic processes like reduction of photosynthetic pigments.

\section{Relative water content}

Relative water content (RWC) is an appropriate trait of plant water status in term of physiological consequence of cellular water deficit. RWC was decreased with increase in temperature and age of plants. Comparatively higher RWC was recorded when crop planted on 1st February than 22nd February and 15th March planted crop at tasselling and silking stage. High temperature is generally characterized in decreasing the RWC, resulting in wilting, stomatal closure and reduced growth (Lawlor and Cornic 2002). Potassium application significantly increased RWC at lower temperature rather than higher temperature (Table VI). Such increase with potassium fertilization may be ascribed to increase osmolytes accumulation in cell which play a major role in osmotic adjustment and also protect by scavenging reactive oxygen species (ROS). Previously, Fanaei et al. (2009) reported that potassium application caused increased RWC at stressful condition in oilseed crops.

\section{Conclusion}

The findings of this study clearly indicate the direct physiological and biochemical effects of $\mathrm{K}$ application in enhancing seedling establishment under chilling and heat stress in spring maize cultivation. Both levels of $\mathrm{K}$ application improved TDM and LAI by reducing oxidative damage and improved growth under stressful conditions through increased chlorophyll contents and inducing POD, CAT and $\mathrm{SOD} /[\mathrm{POD}+\mathrm{CAT}]$ activities.

\section{References}

Ahmad I, Basra SMA, Afzal I, Farooq M and Wahid A (2013), Growth improvement in spring maize through exogenous application of ascorbic acid, salicylic acid and hydrogen peroxide, International Journal of Agriculture and Biology 15: 95-100. 
Ahmad I, Basra SMA and Wahid A (2014), Exogenous application of ascorbic acid, salicylic acid and hydrogen peroxide improves the productivity of hybrid maize at low temperature stress, International Journal of Agriculture and Biology 16: 825-830.

Ahmad I, Basra SMA, Hussain S, Hussain SA, Hafeez-urRehman, Rehman A and Ali A. (2015), Priming with ascorbic acid, salicylic acid and hydrogen peroxide improves seedling growth of spring maize at suboptimal temperature, Journal of Environmental and Agricultural Sciences, 3:14-22.

Apel K and Hirt H (2004), Reactive oxygen species: metabolism, oxidative stress and signal transductions, Annual Review of Plant Biology 55: 373-399.

Asada K (1999), The water cycle in chloroplasts scavenging of active oxygens and dissipation of excess photons. Annual review of plant biology 50: 601-639.

Badawi GH, Yamauchi Y, Shimada E, Sasaki R, Kawano N and Tanaka K (2004), Enhanced tolerance to salt stress and water deficit by overexpressing superoxide dismutase in tobacco (Nicotiana tabacum) chloroplasts, Plant Science 166: 1114-1122.

Balasubramian P and Palaniappan, SP (2001), Principle and practices of Agronomy, Agrobios. (India), Johdpur, PP 21-24.

Salah BH and Tardieu F (1995), Temperature affects expansion rate of maize leaves without change in spatial distribution of cell length, Plant Physiology 109: 861870.

Brar MS and Singh R (1995), Potassium depletion and effects of $\mathrm{K}$ fertilization on soil $\mathrm{K}$ content, growth and $\mathrm{K}$ concentration of maize, Journal of Potassium Research 11: 154-159.

Chance M and Maehly AC (1955), Assay of catalases and peroxidases, Methods Enzymol. 2: 764.

Cherel L (2004), Regulation of $\mathrm{K}^{+}$channel activaties in plants: physiological to molecular aspects, Journal of
Experimental Botany 55: 337-351.

Fanaei HR, Galavi M, Kafi M and Bonjar AG (2009), Amelioration of water stress by potassium fertilizer in two oilseed species, International Journal of Plant Production 3: 41-54.

Cakmak I (2005), The role of potassium in alleviating detrimental effects of abiotic stresses in plants, Journal of Plant Nutrition and Soil Science 168: 521-530.

Ismail AM and Hall AE (1999), Reproductive-stage heat tolerance, leaf membrane thermo stability and plant morphology in cowpea, Crop Science 39: 1762-1768.

Janda T, Szalai G, Kissimon IJ, Paldi E, Marton C and Szigeti Z (1994), Role of irradiance in the chilling injury of young maize plants studied by chlorophyll florescence induction measurements, Photosynthetica 30: 293-299.

Johnson RR and Herrero MP (1981), Corn pollination under moisture and high temperature stress. In Proceedings of the annual corn and sorghum industry research conference, Chicago, II pp. 66-77 (American Seed Trade Association, Washington D.C.

Kafkafi U (1990), Impact of potassium in relieving plants from climatic and soil-induced stresses, In: Food Security in the WANA Region, the Essential Need for Balanced Fertilization, Ed. Johnston AE, International Potash Institute, Basel, pp 317-327.

Kemmler KA (1989), Potassium and stress tolerance. Potassium and fertilizer use efficiency. Proceedings of the workshop on the role of potassium in improving fertilizer use efficiency NFDC, Islamabad. 21-22 March 1987. In: Potassium and fertilizer use efficiency. NFDC. Planning and Development Division Government of Pakistan, Islamabad. P-187-202, 1987.

Lawlor DW and Cornic G (2002), Photosynthetic carbon assimilation and associated metabolism in relation to water deficit in higher plants, Plant Cell and Environment 25: 275-294. 
Maathuis FJM and Sanders D (2006), Mechanisms of potassium absorption by higher plant roots, Physiology Plantarum 96: 158-168.

Meille JL and Pellerin S (2004), Leaf area establishment of a maize (Zea mays L.) field crop under potassium deficiency, Plant and Soil 265: 75-92.

Meille JL and Pellerin S (2008), Shoot and root growth of hydroponic maize (Zea mays L.) as influenced by $\mathrm{K}$ deficiency, Plant and Soil 304: 157-168.

Nagata M and Yamashita I (1992), Simple method for simultaneous determination of chlorophyll and carotenoids in tomato fruit, Journal of Japanese Society of Food Science and Technology 39: 928-928.

Noctor G and Foyor CH (1998), Ascorbate and glutathione: keeping active Oxygen under control, Annual Review of Plant Physiology and Molecular Biology 49: 249279.

Ouchi S, Nishikawa A and Kameda E (1990), Soil improving effect of a super water absorbent polymer II. Evaporation, leaching of salts and growth of vegetables, Japanese Journal of Soil Science and Plant Nutrition 61: 606-613.

Pettigrew WT (2008), Potassium influences on yield and quality production for maize, wheat, soybean and cotton, Physiology Plantarum 133: 670-681.
Sairam RK Shukla DS and Saxena DC (1997), Stress induced injury and antioxidant enzymes in relation to drought tolerance in wheat genotypes, Biologia Plantarum 40: 357-364.

Soleimanzadeh H Habibi D Ardakani MR Paknejad F and Rejali F (2010), Effect of potassium levels on antioxidants enzymes and malendealdehyde content under drought stress in sunflower (Helianthus annus L.), American Journal of Agriculture and Biological Science 5: 56-61.

Steel RG D, Torrie TH and Dickey DA (1997), Principles and Procedures of Statistics A Biometrical Approach. $3^{\text {rd }}$ Ed. McGraw Hill Book International Co. Inc., Singapore, pp. 204-232.

Tisdale SL, Nelson WL and Beaton JD (1990), Soil fertility and fertilizer. Elements required in plant nutrition. $4^{\text {th }}$ Ed. Maxwell McMillan Publishing, Singapore, pp. 5292.

Wahid A, Gelani S, Ashraf M and Foolad MR (2007), Heat tolerance in plants: An Overview of Environmental and Experimental Botany 61: 199-223.

Received: 14 September 2015; Revised: 15 Ocotober 2015; Accepted: 19 Ocotober 2015. 